\title{
Trend Analysis and Simulation of Human Vulnerability Based on Physical Factors of Riverbank Erosion Using RS and GIS
}

\author{
Tayabur Rashid Chowdhury ${ }^{1}$. Zia Ahmed ${ }^{1}$. Sabina Islam ${ }^{2}$. Shetu Akter ${ }^{1}$. Shrinidhi Ambinakudige ${ }^{3}$. \\ Hsiang-te Kung ${ }^{4}$
}

Received: 9 June 2021 / Revised: 19 July 2021 / Accepted: 20 July 2021 / Published online: 30 July 2021

(C) The Author(s) 2021

\begin{abstract}
This study aims to analyze the pattern of bank erosion and simulate the physical aspects of vulnerability in the lower Meghna River, Bangladesh using remote sensing (RS) and geographic information systems (GIS). The physical factors of vulnerability were analyzed using GIS-based Structured Query Language (SQL). A questionnaire survey, GPS survey and field observation survey were conducted for collecting the primary data in the study area. The secondary data were mainly satellite image collected from the United States Geological Survey (USGS) website. Using time series Landsat images (MSS, TM and OLITIRS), this study analyzed 36 years of erosion and accretion process in the Mehendiganj Upazila region from 1980 to 2016. The result indicates that an enormous amount of land ( $4470.47 \mathrm{ha}$ ) was submerged by the river and average land loss rate was $124.18 \mathrm{ha} /$ year. The study quantifies the number of vulnerable households beneath the present condition and how much it will be altered after a positive/negative change with the factors of vulnerability related to the households. Simulation data reveals that under the present physical condition, $43.88 \%$ of households were identified as severely vulnerable. The output of this study can be used in the classification of vulnerable households and for the improvement of the physical infrastructure development process near the erosion prone areas, also helps to mitigate environmental disaster in the developing countries.
\end{abstract}

Keywords Riverbank erosion $\cdot$ Vulnerability $\cdot$ Erosion $\cdot$ Accretion $\cdot$ Simulation $\cdot$ Riverine disaster

Zia Ahmed

ziaahmed-gee@sust.edu

Tayabur Rashid Chowdhury

tayabur.chowdhury@ student.sust.edu

Sabina Islam

sabina-sta@sust.edu

Shetu Akter

shetuakter-gee@sust.edu

Shrinidhi Ambinakudige

shrinidhi@geosci.msstate.edu

Hsiang-te Kung

hkung@memphis.edu

1 Department of Geography and Environment, Shahjalal University of Science and Technology, Sylhet, Bangladesh

2 Department of Statistics, Shahjalal University of Science and Technology, Sylhet, Bangladesh

3 Department of Geosciences, Mississippi State University, Starkville, USA

4 Department of Earth Sciences, The University of Memphis, Memphis, USA

\section{Introduction}

Bangladesh is the land of natural disasters. It is situated beside the world's largest rivers (the Brahmaputra, the Ganges, and the Meghna river) delta where erosion is a common phenomenon. Erosion is a very common morphological development in sedimentary plain rivers. Erosion of riverbank and shifting of river channel create many problems for Bangladesh in both socio-economic and environmental sectors (Klaassen et al. 2002). Riverbank erosion means the fragmentation or transferring away the sediments of the riverbank by itself which causes river channel bend (Fujita et al. 2000). In recent years, a number of researchers have investigated riverbank erosion and river channel shifting. (Phillip et al. 1989; Madej et al. 1994; Tangri 2000; Das and Saraf 2007; Das et al. 2007; Pati et al. 2008; Saleem et al. 2020). Water is the most common cause of soil erosion. Water is the main agent which causes the river basin degradation along with landforms and seashore changes. The massive rivers of Bangladesh viz., Jamuna, Padma, and Meghna have altered their 
sequences suddenly causing riverbank erosion. Melting icecaps is generating huge amount of flowing water which leads to the increase in downward rivers flow.

The main three rivers (the Padma, the Meghna and the Jamuna) of Bangladesh have eroded around 1,59,000 ha of their floodplains since 1973. Around 1.6 million people of Bangladesh became homeless due to riverbank erosion. People who are living in the floodplains and char land have become helpless due to riverbank erosion (Aktar 2013a). The Meghna and Padma rivers both run from north to south, forming the Meghna estuary before entering the Bay of Bengal. In addition, the Meghna River is also morphologically a low-energy, multi-channel fluvial system, characterized by a system of linking channels and inter-channel region (Alam 1991). The maximum discharge of the Meghna river recorded $20,000 \mathrm{~m}^{3} / \mathrm{s}$ at the confluence point of the Padma-Meghna and 160,000 $\mathrm{m}^{3} / \mathrm{s}$ at the lower Meghna with the slope of $5 \mathrm{~cm} / \mathrm{km}$ (Haskoning 1992). The magnitude of erosion and accretion within the Meghna estuary varies spatially. During the period 1973-2010, huge amount ( 98,079 ha) of land were eroded by the Lower Meghna river (CEGIS 2012). When riverbank erosion occurs, a large number of displaced individuals abandon their original homestead land and seek permanent or temporary refuge in the embankment or on neighboring land (Rahman 2010).

According to different studies perspective, vulnerability is the preliminary ground of disaster as well as the function of hazard susceptibility and coping capacity of the households to decrease risk at a particular point in time (Smit and Wandel 2006; Adger 2006; Emrich and Cutter 2011; Paul 2013; Akter and Mallick 2013; Blaikie et al. 2014; Hossain 2015; Bhuiyan et al. 2017; Hossain and Paul 2018). These studies focused on to determine the relationship between physical and socio-economic factors affecting a household and its vulnerability to peripheral force such as natural calamities. Respectively, vulnerability is described as an inner risk factor of a person or system exposed to a hazard that corresponds to the subject's or systems innate inclination to be impacted or vulnerable to damage (Paul 2013). Similarly, human vulnerability is the social, economic, and physical susceptibility or trend of a community to be damaged or altered by a natural or anthropogenic calamity. GIS is effective tools equipped with storing, organizing, analyzing, and presenting large spatial data (Salam et al. 2003; Taramelli et al. 2015). National and regional planning, emergency and disaster management, vulnerability simulation and reduction have all benefited from the use of GIS (Salam et al. 2003; Roche et al. 2013; Taramelli et al. 2015; Ali et al. 2019a). Simulation technique, on the other hand, is defined as the replication of the activity of a real-world sequence of operations across time (Sokolowski and Banks 2011; Srivastava 2015).
Riverbank erosion is a regular and widely destructible hazard in Bangladesh. Every year thousands of hectors of land get eroded by the mighty rivers of Bangladesh and make thousands of people homeless. Especially, the lower Meghna basin area is widely affected by riverbank erosion. There has been little scientific research work about simulation of human vulnerability based on physical factors of the riverbank erosion rather more concentration was given in deals with geomorphic phenomena and bank shifting. Most of the researchers focused on the overall erosion caused by a major river rather than to estimate the total erosion caused by different rivers (small/large) around a geographical area that are vulnerable to riverbank erosion (Madej et al. 1994; Thakur et al. 2011; Nath et al. 2013; Aktar 2013b; Bhuiyan et al. 2014; Saleem et al. 2020). On the other hand, this research work emphasized to assess total land loss of a geographical area (Mehendiganj Upazila) due to riverbank erosion. In case of riverbank erosion induced vulnerability assessment while other study mainly focused on the socio-economic factors (Haque and Hossain 1988; Bhuiyan et al. 2017; Debnath et al. 2016; Roy et al. 2017), this study focused on the physical factors and vulnerable household through GIS-based simulation.

Therefore, the primary goal of this research is to examine the trend of riverbank erosion and simulate the physical factors that contribute to human vulnerability using both primary and secondary data. Furthermore, this study tries to link up between the spatial patterns of riverbank erosion to human vulnerability.

\section{Methodology}

\subsection{Location of the Study Area}

Mehendiganj Upazila is positioned between the latitudes of $22.68^{\circ}$ and $23.91^{\circ}$ north, and the longitudes of $90.38^{\circ}$ and $90.63^{\circ}$ east (Fig. 1). The total area of Mehendiganj Upazila is about $418.98 \mathrm{sq} \mathrm{km}$, and total population is 304,364 (BBS 2011). Mehendiganj is a confined geographical area surrounded by river in all the side. The Upazila is located on the lower Meghna floodplain, surrounded by different rivers such as Meghna, Arial Khan, Tetulia, Lata, Dharmaganj, Naya Bhanga, Chilmari, Azimpur, and Sultani (Banglapedia). Riverbank erosion is a severe and frequent phenomenon in Mehendiganj Upazila. Two erosion prone villages (Hasanpur and Asa) of Mehendiganj Upazila were selected for the study.

\subsection{Data}

The primary data were gathered through a questionnaire survey, GPS survey, direct field observation, and interviews 
Fig. 1 Map of the study area
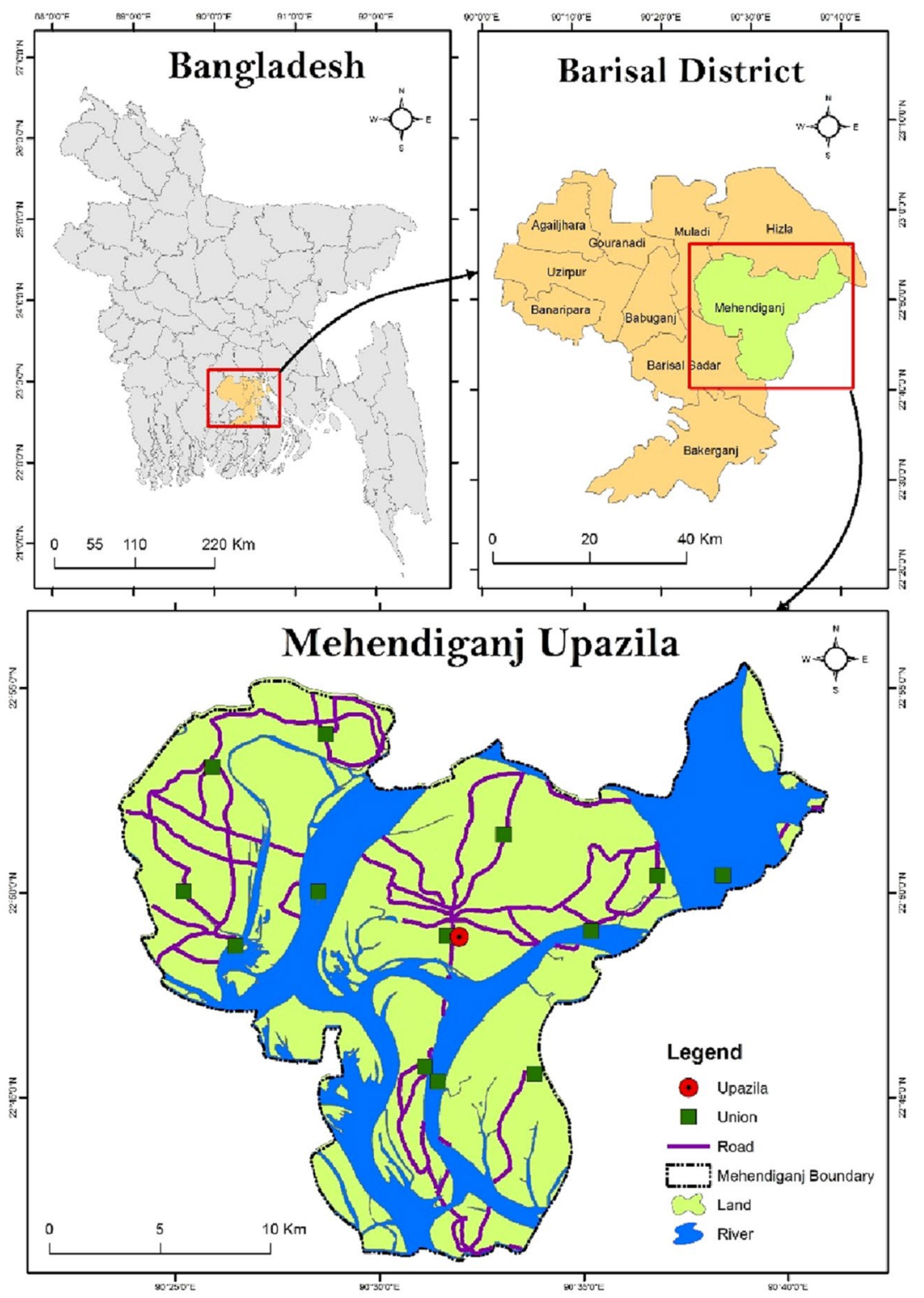

with the study's target group. The secondary data were collected from USGS. The collected imagery was pre-georeferenced and geometrically corrected Level-1 Landsat data. Other secondary data were collected from different government offices, e.g., Mehendiganj Upazila office, Upazila Agriculture office and Union Parishad office. To analyze 36 years of riverbank erosion, five Landsat satellite time series image (Table 1) were collected.

\subsection{Simulation Process}

For the simulation of human vulnerability based on physical factors of riverbank erosion GIS-based SQL and mapping systems were used (Hossain and Paul 2017). The simulation was based on collected data sets (both primary and secondary) under the different changing scenarios. Different
Table 1 Description of Landsat images

\begin{tabular}{llllll}
\hline Acquired date & Satellite & Sensor & Path/Row & $\begin{array}{l}\text { Spatial } \\
\text { resolu- } \\
\text { tion }\end{array}$ & $\begin{array}{l}\text { Cloud } \\
\text { cover- } \\
\text { age }\end{array}$ \\
\hline $4 / 12 / 1980$ & Landsat 3 & MSS & $147 / 44$ & 60 & 0 \\
$19 / 02 / 1988$ & Landsat 5 & TM & $137 / 44$ & 30 & 0 \\
$25 / 12 / 1996$ & Landsat 5 & TM & $137 / 44$ & 30 & 0 \\
$21 / 12 / 2006$ & Landsat 5 & TM & $137 / 44$ & 30 & 0 \\
$16 / 12 / 2016$ & Landsat 8 & OLI-TIRS & $137 / 44$ & 30 & 0 \\
\hline
\end{tabular}

Source: USGS

categories of risk factors (physical factors) and degree of judgment for simulation were established by field inspection and key informants' information. 


\subsection{Sample Design and Procedure}

Simple random sampling techniques were used to decide the sample of households from the study areas. Considering 5\% significance level, the projected sample size is 278 (Hasanpur Village 115 and Asa Village 163) out of a total of 917 households. By adopting Yamane formula (1967), the sample size was calculated (Eq. 1):

$n=\frac{N}{1+N e^{2}}$

\subsection{Satellite Image Processing}

The radiometric correction and atmospheric correction have been performed on all the images. Equation (2) was used for the $D N$ value to radiance value conversion, and Eq. (3) was used to convert radiance values $(L \lambda)$ into atmospheric reflectance. From the USGS website, the $E_{\text {sun }}$ value for both Landsat 3 and Landsat 5 were gathered. Landsat 8 image was converted using Eq. (4) from the Landsat 8 handbook. In case of atmospheric correction, Dark Object Subtraction (DOS) was accomplished by ENVI 5.1 software using band minimum method:

$$
\begin{aligned}
& L_{\lambda}=\frac{L_{\max \lambda}-L_{\text {min } \lambda}}{Q_{\text {calmax }}-Q_{\text {calmin }}} \times\left(Q_{\text {calmax }}-Q_{\text {calmin }}\right)+L_{\text {min } \lambda} \\
& \rho=\frac{\pi L_{\lambda} d^{2}}{E_{\text {sun }} \cos \theta_{s}} \\
& L_{\lambda}=\mathrm{MLQ}_{\text {cal }}+A_{L}
\end{aligned}
$$

\subsection{Image Classification and Area Measurement}

Using a density slicing method, the satellite images were first classified into binary images water and non-water classes (Wang et al. 2002). To find out the extent of water bodies, one single band (infrared band) has been classified.
The infrared band presents an improved illustration in the water-related attributes than the visible bands (Jain et al. 2005). Erdas Imagine 2014 software was used for images classification. The classified image has been converted into vector format using ArcGIS raster to vector tool. The land area of erosion and accretion were identified using superimposition method. The land areas of different stages were calculated by geometry and field calculator tools of ArcGIS attribute table.

\section{Results and Discussion}

\subsection{Riverbank Erosion Trend in Mehendiganj Upazila}

Table 2 illustrates 36 years of erosion and accretion scenarios from 1980 to 2016. Erosion rate was highest from 1988 to 1996 with 536.66 ha/year, 4293.26 ha land was eroded subsequent 8 years period during 1988-1996. Erosion rate was also higher between 2006 and 2016 with 516.10 ha/year (Fig. 2; Table 2). Total 5160.98 ha of land was eroded in the last 10 years period. In these 36 years, average erosion rate was calculated as $453.88 \mathrm{ha} /$ year with the total erosion of 16,339.74 ha land (Table 2). Figure 2 represents the visual representation of the total accretion and erosion scenario of Mehendiganj Upazila.

The average accretion rate in Mehendiganj Upazila was 329.7 ha/year in Mehendiganj Upazila between 1980 and 2016 (Table 2). The highest accretion rate was observed in 1996-2006 and was 414.08 ha/year (Table 2; Fig. 2). The land area increased by 4140.84 ha in that period. During 2006-2016, the accretion rate was 228.27 ha/year which extended the land area by 2282.75 ha (Table 2 ).

It is showed that the percentage of changes in land area due to erosion and deposition process and from 1980 to 1988 accretion rate was exalted than erosion rate, and the opposite phenomenon occurred within the year 1988-1996 where land area decreased by 2090.57 ha (Table 2). Among the four periods, the most devastating period was 2006-2016, where 2878.23 ha land was vanished in this period (Fig. 2).

Table 2 Erosion and deposition scenario of Mehendiganj Upazila from 1980 to 2016

\begin{tabular}{lllllllr}
\hline Period & $\begin{array}{l}\text { Total erosion } \\
\text { (ha) }\end{array}$ & $\begin{array}{l}\text { Erosion rate } \\
\text { (ha/year) }\end{array}$ & $\begin{array}{l}\text { Average erosion } \\
\text { rate } \\
\text { (ha/year) }\end{array}$ & $\begin{array}{l}\text { Total accretion } \\
\text { (ha) }\end{array}$ & $\begin{array}{l}\text { Accretion rate } \\
\text { (ha/year) }\end{array}$ & $\begin{array}{l}\text { Average accre- } \\
\text { tion rate } \\
\text { (ha/year) }\end{array}$ & $\begin{array}{l}\text { Land area } \\
\text { change } \\
\text { (ha) }\end{array}$ \\
\hline $1980-1988$ & 2978.14 & 372.27 & $\mathbf{4 5 3 . 8 8}$ & 3242.99 & 405.37 & $\mathbf{3 2 9 . 7 0}$ & 264.86 \\
$1988-1996$ & 4293.26 & 536.66 & & 2202.70 & 275.34 & -2090.57 & -6.40 \\
$1996-2006$ & 3907.36 & 390.74 & & 4140.84 & 414.08 & 233.48 \\
2006-2016 & 5160.98 & 516.10 & & 2282.75 & 228.27 & 0.76 \\
Total & $\mathbf{1 6 , 3 3 9 . 7 4}$ & N/A & & $\mathbf{1 1 , 8 6 9 . 2 8}$ & N/A & -2878.23 & -9.34 \\
\hline
\end{tabular}

The bold text is used for better visual and emphasize the values 

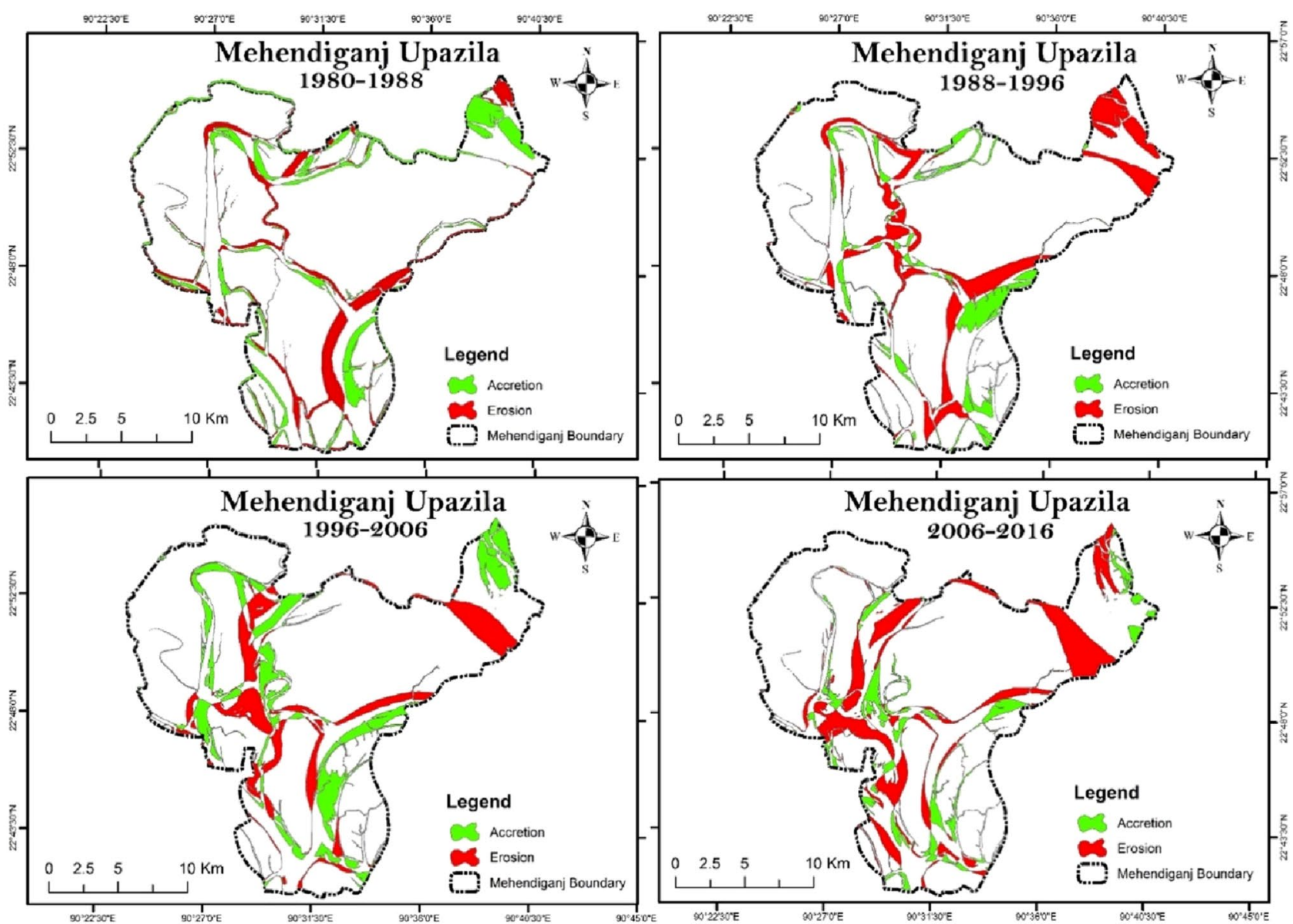

Fig. 2 Riverbank erosion and accretion of Mehendiganj Upazila

Throughout this study period (36 years), total land loss was estimated 4470.47 ha with a rate of 124.18 ha/year (Table 2).

\subsection{Simulation of Factors of Human Vulnerability}

The physical aspects of human vulnerability to riverbank erosion were simulated. The simulation was run in a variety of scenarios and with a variety of judgmental criteria. The factors' values were either satisfactorily (positively) or unfavorably (negatively). The study reveals the present scenario of vulnerability in the household level, contrariwise conditional scenarios under the projected change of current conditions of vulnerability.

\subsubsection{Simulation of Physical Factors}

Two physical factors were taken consideration which may affect human vulnerability to riverbank erosion. Elevation of house from MSL and the remoteness of the river from the residence were two physical factors used in the simulation (Table 3). Progress and degradation of the current condition under favorable (positive) and unfavorable (negative)

Table 3 Physical factors of simulation process

\begin{tabular}{|c|c|c|c|}
\hline \multirow[t]{2}{*}{ Vulnerability factors } & \multirow{2}{*}{$\begin{array}{l}\text { Degree of evaluation of } \\
\text { present status }\end{array}$} & \multicolumn{2}{|l|}{ Modifications of simulation } \\
\hline & & Positive alteration & Negative alteration \\
\hline $\begin{array}{l}\text { 1. Distance from river to the } \\
\text { house (in meter) }\end{array}$ & $\begin{array}{l}\text { Moderate near } \\
\text { (less than } 400 \mathrm{~m} \text { ) }\end{array}$ & $100 \mathrm{~m}$ addition to the current distance & $100 \mathrm{~m}$ reduction to current distance \\
\hline $\begin{array}{l}\text { 2. Elevation of house (in feet } \\
\text { from MSL) }\end{array}$ & $\begin{array}{l}\text { Moderate } \\
\text { (less than } 30 \text { feet) }\end{array}$ & $5 \mathrm{ft}$ addition to the current elevation & $5 \mathrm{ft}$ reduction to the current elevation \\
\hline
\end{tabular}


scenarios were taken into account for the simulation of collected data. The households in this study were given a standard altitude of 30 feet to investigate their current vulnerability status (Table 3). 5 feet elevation was, respectively, increased and decreased with present status to visualize the changes (positive and negative). House which was situated $400 \mathrm{~m}$ from the river was taken as standard. On the other hand, $100 \mathrm{~m}$ remoteness was, respectively, increased and lessened with current values of all household's distance (Table 3).

In the study period based on existing physical structure of households, $43.88 \%$ were identified as severely vulnerable households (Fig. 3). In contrast, for the changing of physical environment, the quantity of most vulnerable households was changed. Sahana and Sajjad (2019) conducted a study in the Sundarbans nearly half of the villages are highly vulnerable and have limited capacity in the case of a natural disaster. The most vulnerable villages situated in the lower elevation, whereas higher elevation showed low vulnerability. Ali et al. (2019b) worked on a vulnerability mapping due to flood and estimate the vulnerable area using GISbased AHP approaches. The findings revealed that distance from the river, differences in rainfall, and land use land cover all play a significant role in flooding, and that a GIS-based model can help identify vulnerable areas and assess potential risk areas. Table 4 indicates that when physical factors
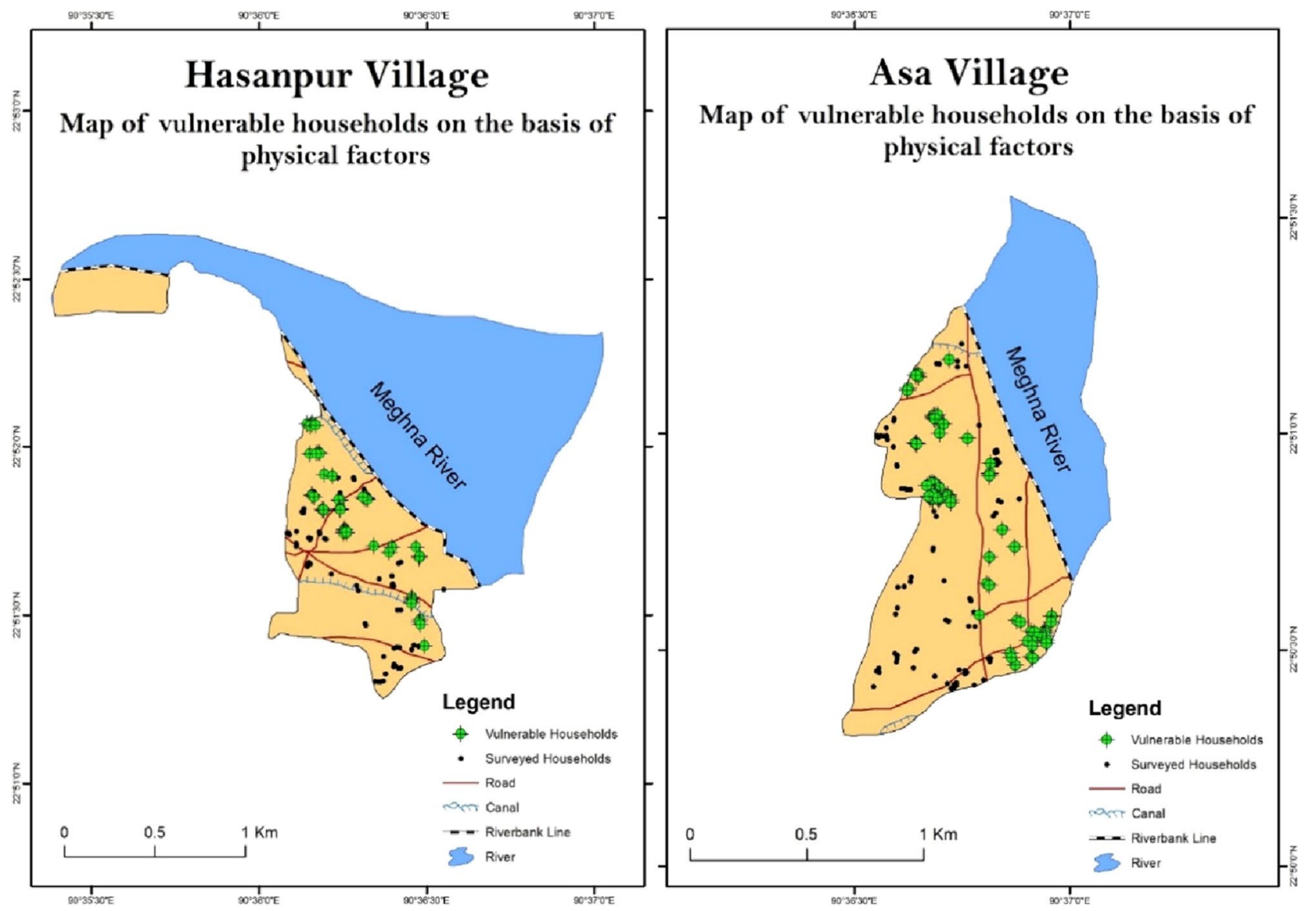

Fig. 3 Most vulnerable households based on physical factors

Table 4 Result of the simulation of the physical factors

\begin{tabular}{|c|c|c|c|c|c|c|}
\hline \multirow[t]{2}{*}{ Assessment scenario } & \multicolumn{2}{|c|}{ Hasanpur } & \multicolumn{2}{|l|}{ Asa } & \multicolumn{2}{|c|}{ Total } \\
\hline & $\mathrm{HH}$ & $\%$ & $\mathrm{HH}$ & $\%$ & $\mathrm{HH}$ & $\%$ \\
\hline Existing vulnerability & 50 & 43.48 & 72 & 44.17 & 122 & 43.88 \\
\hline After positive change & 84 & 73.04 & 118 & 72.39 & 202 & 72.66 \\
\hline After negative change & 21 & 18.26 & 21 & 12.88 & 42 & 15.11 \\
\hline
\end{tabular}

Source: result of simulation 
changed in a positive way, the number of vulnerable households climbed up to $72.66 \%$ (Table 4; Fig. 4). In contrast, after a negative change in physical factors of human vulnerability, the number of vulnerable households declined by $15.11 \%$ (Table 4; Fig. 5).

\subsubsection{Simulation Based on Previous Riverbank Erosion Impacts}

Different factors of previous riverbank erosion impacts were simulated in the vulnerability template (Table 5). Selected characteristics was the number of $\mathrm{HH}$ experience riverbank erosion, amount of land loss, monthly income decrease by the household and overall damage caused by riverbank erosion. For the simulation of data, progress and degradation of present condition were taken into consideration, respectively, under the favorable (positive) and non-favorable (negative) situations. For the assessment of existing scenario of vulnerability, 1 time was considered as the standard for household-experienced riverbank erosion, 1 time reduction and 1 time addition with the present value to visualize the positive and negative change. In case of land loss,
100 decimals were taken as standard and 50 decimals are decreased and increased to find the positive and negative scenarios.

Similarly, to simulate the present condition, Tk. 2000 is considered as the standard amount of monthly income decreased by the household and 1000 reduction and addition to simulate both favorable and unfavorable shift, respectively. Finally, the existing value of damage of household factor was defined risk degree 2 (High) and 1 degree down and up for visualizing the positive and negative change scenario (Table 5).

In the current situation, $15.11 \%$ of households were recognized as severely vulnerable (Table 6; Fig. 6). Conversely, due to transform of the previous situation the numbers of most vulnerable households were changed. If the positive change or considered less severe previous impact, then the quantity of vulnerable households will be reduced by $3.95 \%$ of total households (Table 6; Fig. 7). Conversely, the numbers were increased by $18.71 \%$ after a negative change of previous impact of human vulnerability (Fig. 8). Hossain and Paul (2017) investigated cyclones and storm surges vulnerability based on socio-economic and physical factors
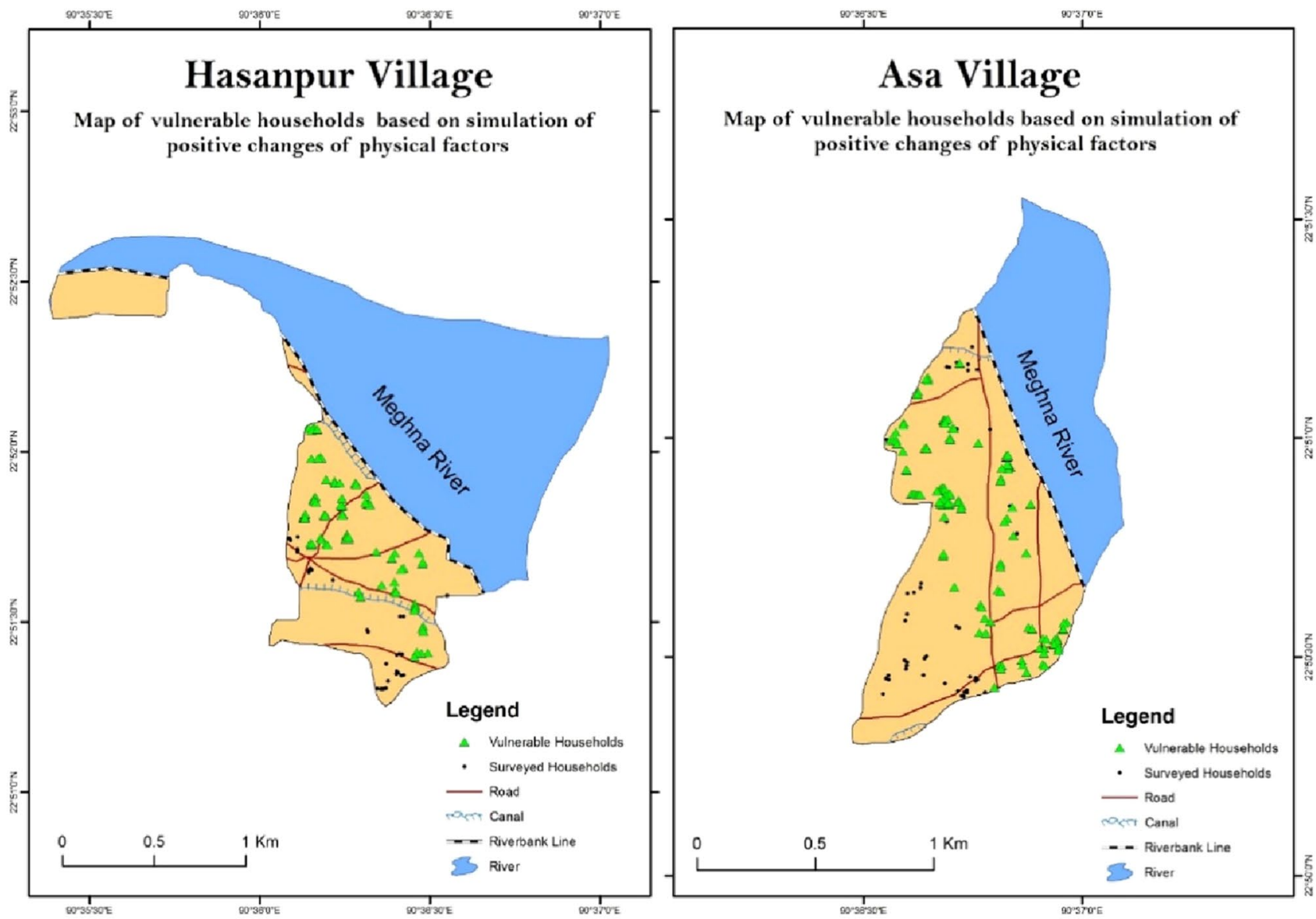

Fig. 4 Simulated vulnerable households based on positive alterations of physical factors 

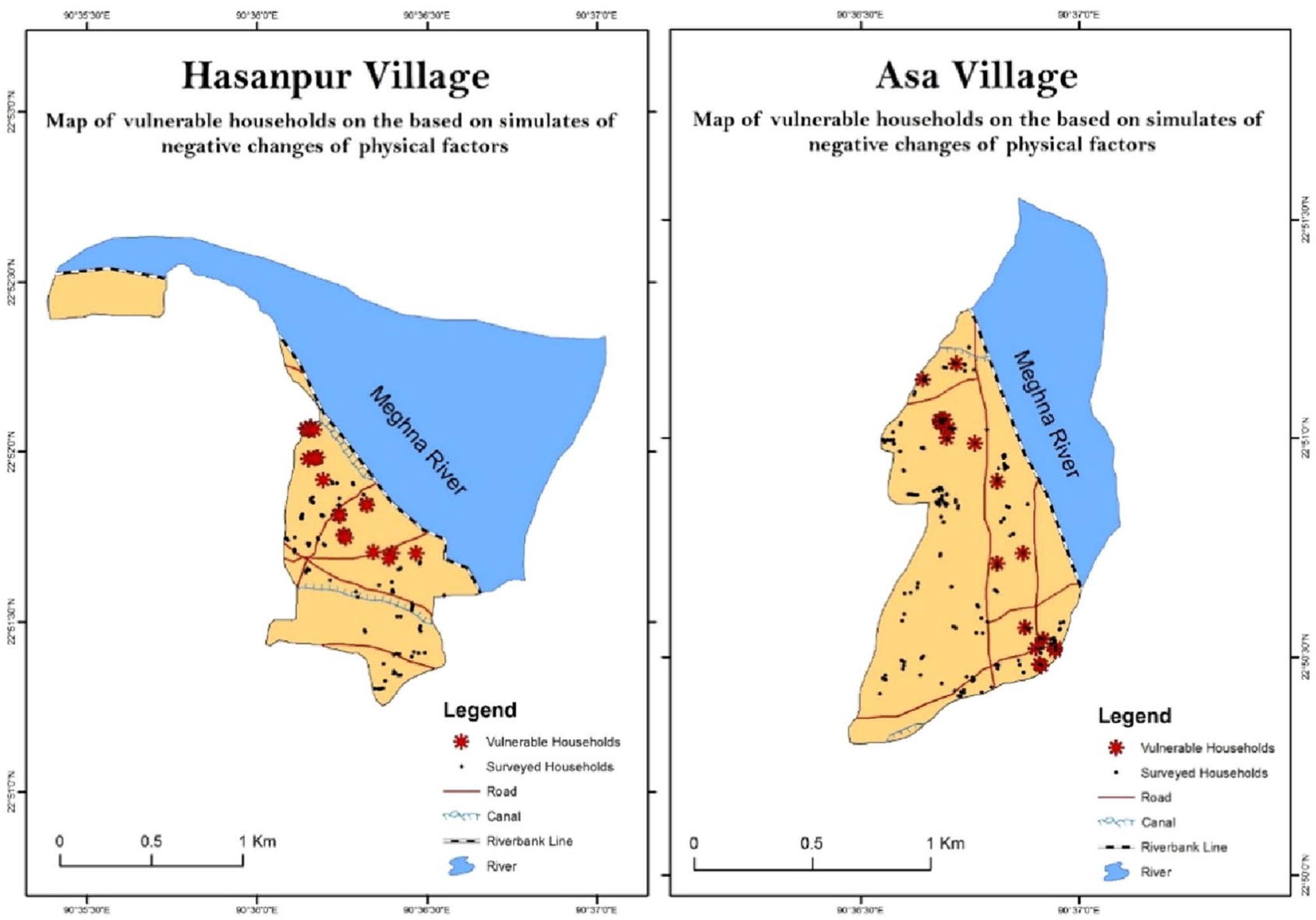

Fig. 5 Simulated vulnerable households based on negative alterations of physical factors

Table 5 Previous riverbank erosion impact factors simulation process

\begin{tabular}{|c|c|c|c|}
\hline \multirow[t]{2}{*}{ Vulnerability factors } & \multirow{2}{*}{$\begin{array}{l}\text { Degree of evaluation } \\
\text { of present status }\end{array}$} & \multicolumn{2}{|l|}{ Modifications of simulation } \\
\hline & & Positive alteration & Negative alteration \\
\hline $\begin{array}{l}\text { 1. The times household-experienced } \\
\text { riverbank erosion }\end{array}$ & $1 /$ more than 1 & 1 time reduction from present value & 1 time addition from present value \\
\hline $\begin{array}{l}\text { 2. Land loss of the household (deci- } \\
\text { mal) }\end{array}$ & $\begin{array}{l}100 \text { decimals } \\
\text { (moderate) }\end{array}$ & $\begin{array}{l}50 \text { decimal reductions from present } \\
\text { value }\end{array}$ & $\begin{array}{l}50 \text { addition reduction from present } \\
\text { value }\end{array}$ \\
\hline $\begin{array}{l}\text { 3. Income decrease of the household } \\
\text { (TK per month) }\end{array}$ & $\begin{array}{l}\text { High risky } \\
\text { (more than } 2000 \mathrm{TK} \text { ) }\end{array}$ & $\begin{array}{l}1000 \text { TK reduction from the present } \\
\text { value }\end{array}$ & $1000 \mathrm{TK}$ addition with the present value \\
\hline 4. Damages of the household & High & Moderate & Very high \\
\hline
\end{tabular}

Table 6 Results of the simulation using the previous riverbank erosion impact

\begin{tabular}{|c|c|c|c|c|c|c|}
\hline \multirow[t]{2}{*}{ Assessment scenario } & \multicolumn{2}{|c|}{ Hasanpur } & \multicolumn{2}{|l|}{ Asa } & \multicolumn{2}{|c|}{ Total } \\
\hline & $\mathrm{HH}$ & $\%$ & $\mathrm{HH}$ & $\%$ & $\mathrm{HH}$ & $\%$ \\
\hline Existing vulnerability & 14 & 12.17 & 28 & 17.18 & 42 & 15.11 \\
\hline After positive change & 4 & 3.48 & 7 & 4.29 & 11 & 3.95 \\
\hline After negative change & 26 & 22.61 & 26 & 15.95 & 52 & 18.71 \\
\hline
\end{tabular}

Source: result of simulation 

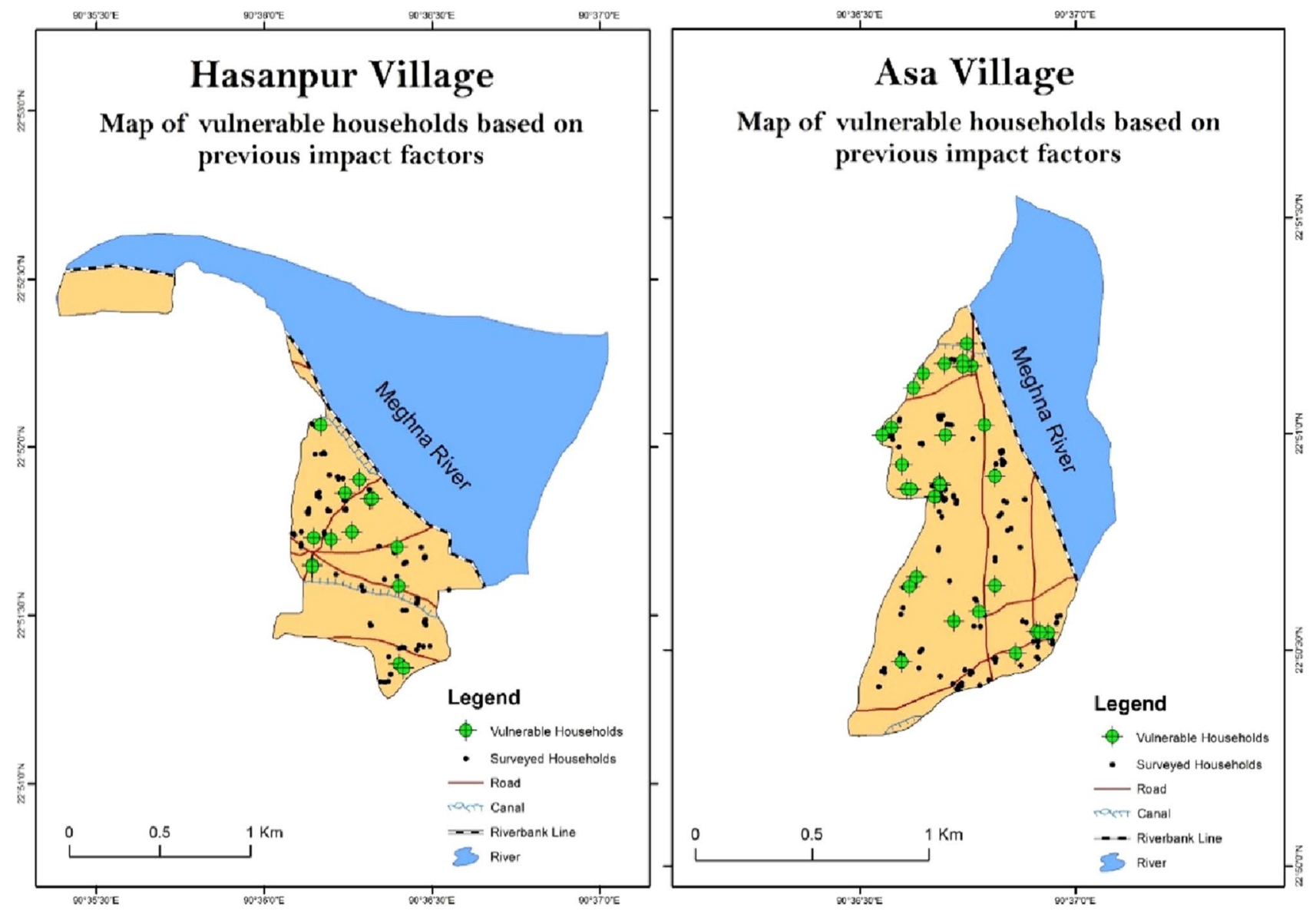

Fig. 6 Most vulnerable households based on previous impact factors

using GIS. Their findings indicate that for human vulnerability assessment, socio-economic and physical elements play a crucial role in determining a household's level of vulnerability. Findings also suggest the extent of household's vulnerability is changed concerning physical and socio-economic condition.

\subsubsection{Simulation of Coping Capacity Factors}

From the literature and local inhabitant's perspective of the study area, several coping capacity factors were taken into consideration. The coping capacity factor includes landholdings, financial help source and savings of the household. For the simulation of data, progress and degradation of the present condition were taken into consideration, respectively under the favorable (positive) and nonfavorable (negative) situations. To detect the current status of vulnerability 25 decimal was taken as standard land area owned by the households. To visualize the positive and negative change, 10 decimal lands was either increased or decreased with present status. In case of financial help source, risk level $2 \mathrm{~m}$ was taken as standard (Table 7). Level 1 was lessened with present values of all household's condition in positive change, no option for negative change in this case. In case of savings of the household factor, the households have no savings considered as the standard value. The answer yes (have savings) was taken as positive change and in this case, there is no negative change scenario (Table 7).

Under the obtainable coping capacity situation of households, $32.37 \%$ were identified as severely vulnerable households (Table 8; Fig. 9). Alternatively, due to modification in coping capacity, the numbers of the most vulnerable households have changed. If coping capacity improves, the number of vulnerable household's falls by $5.04 \%$ of total households (Table 8; Fig. 10). Conversely, the number has been increased by $29.50 \%$ after a negative change of coping capacity factors of human vulnerability (Table 8; Fig. 11). It has been observed that modifying the coping capacity factors can vary the degree of vulnerability of a household under study. 

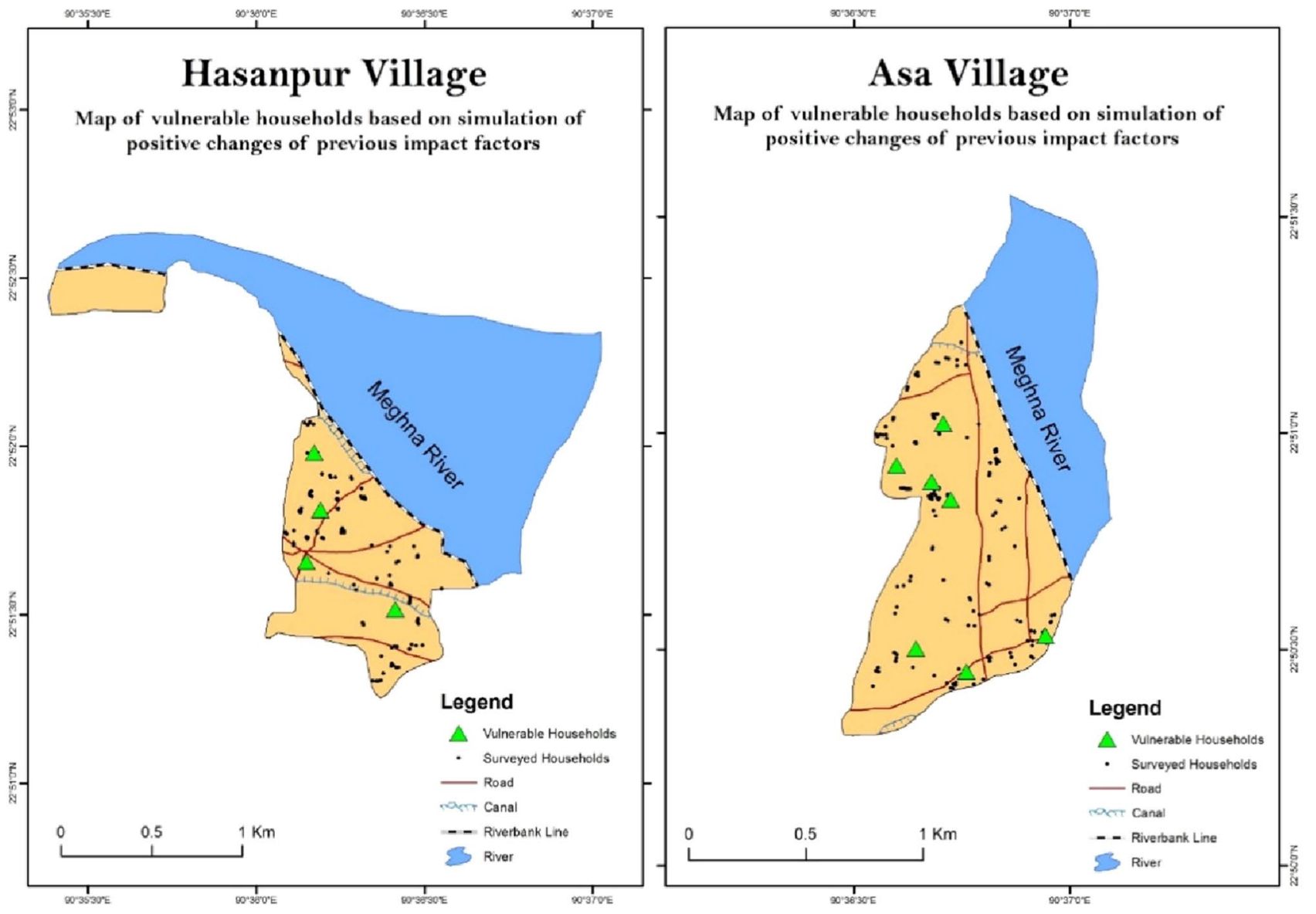

Fig. 7 Simulated vulnerable households based on the positive alterations of previous impact factors

\section{Conclusions}

The study demonstrated the trend of riverbank erosion and simulates the people's vulnerability due to riverbank erosion. However, according to the findings of this study, riverbank erosion eroded approximately one-seventh of the land in Mehendiganj Upazila during the study period. The simulation's results show that physical elements play an important role in determining vulnerable households, and that the extent of a household's vulnerability varies depending on the physical aspects. Household's location and elevation, the remoteness of households was recognized as the main factors affecting the human vulnerability to the riverbank erosion scenario. Spatio-temporal information about the trend of river erosion patterns with a combination of simulation helps to identify the most vulnerable households in the erosion prone area of any countries. The study provides useful tools for the future to build knowledge and data networks about vulnerable households, which can be used to enhance economic resilience and coping capacity of households near the riverside area. The output of this study will be helpful for government and related authorities to realize the promulgation of policy related to riverbank erosion and take proper actions for the displaced people due to riverine disaster. This research work also helps the decision makers to take the initiatives for the implementation of modern technologies to control riverbank erosion which will ultimately reduce environmental vulnerability. 

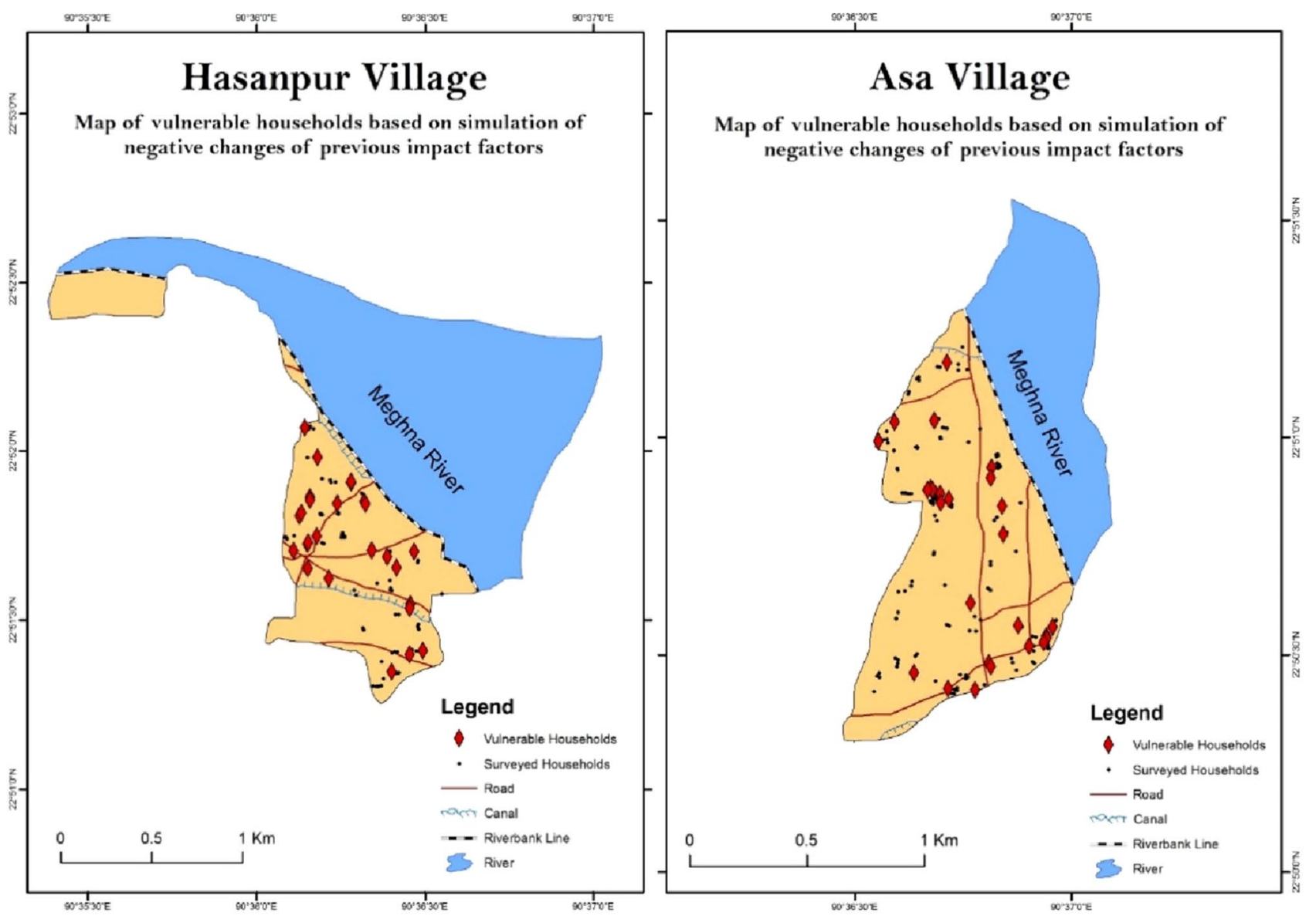

Fig. 8 Simulated vulnerable households based on the negative alterations of previous impact factors

Table 7 Coping capacity factors of simulation process

\begin{tabular}{|c|c|c|c|}
\hline \multirow[t]{2}{*}{ Vulnerability factors } & \multirow{2}{*}{$\begin{array}{l}\text { Degree of evaluation of present } \\
\text { status }\end{array}$} & \multicolumn{2}{|l|}{ Modifications of simulation } \\
\hline & & Positive alteration & Negative alteration \\
\hline $\begin{array}{l}\text { 1. Land owned by the household } \\
\text { (decimal) }\end{array}$ & Less than 25 decimals & $\begin{array}{l}10 \text { decimal additions with the } \\
\text { present value }\end{array}$ & $\begin{array}{l}10 \text { reduction addition with the } \\
\text { present value }\end{array}$ \\
\hline 2. Financial help source & $\begin{array}{l}\text { Risk level } 2 \\
\text { (NGO/Village Mahajan) }\end{array}$ & $\begin{array}{l}\text { Risk level } 1 \\
\text { (relatives/neighbors) }\end{array}$ & * No option for negative change \\
\hline 3. Savings of the household & $\begin{array}{l}\text { No } \\
\text { (High risk) }\end{array}$ & Yes & *No option for negative change \\
\hline
\end{tabular}

*Emphasize that there is no option for negative change for that particular factor

Table 8 Results of the simulation of the coping capacity factors

\begin{tabular}{|c|c|c|c|c|c|c|}
\hline \multirow[t]{2}{*}{ Assessment scenario } & \multicolumn{2}{|c|}{ Hasanpur } & \multicolumn{2}{|l|}{ Asa } & \multicolumn{2}{|c|}{ Total } \\
\hline & $\mathrm{HH}$ & $\%$ & $\mathrm{HH}$ & $\%$ & $\mathrm{HH}$ & $\%$ \\
\hline Existing vulnerability & 42 & 36.52 & 48 & 29.45 & 90 & 32.37 \\
\hline After positive change & 7 & 6.09 & 7 & 4.29 & 14 & 5.04 \\
\hline After negative change & 41 & 35.65 & 41 & 25.15 & 82 & 29.50 \\
\hline
\end{tabular}

Source: result of simulation 

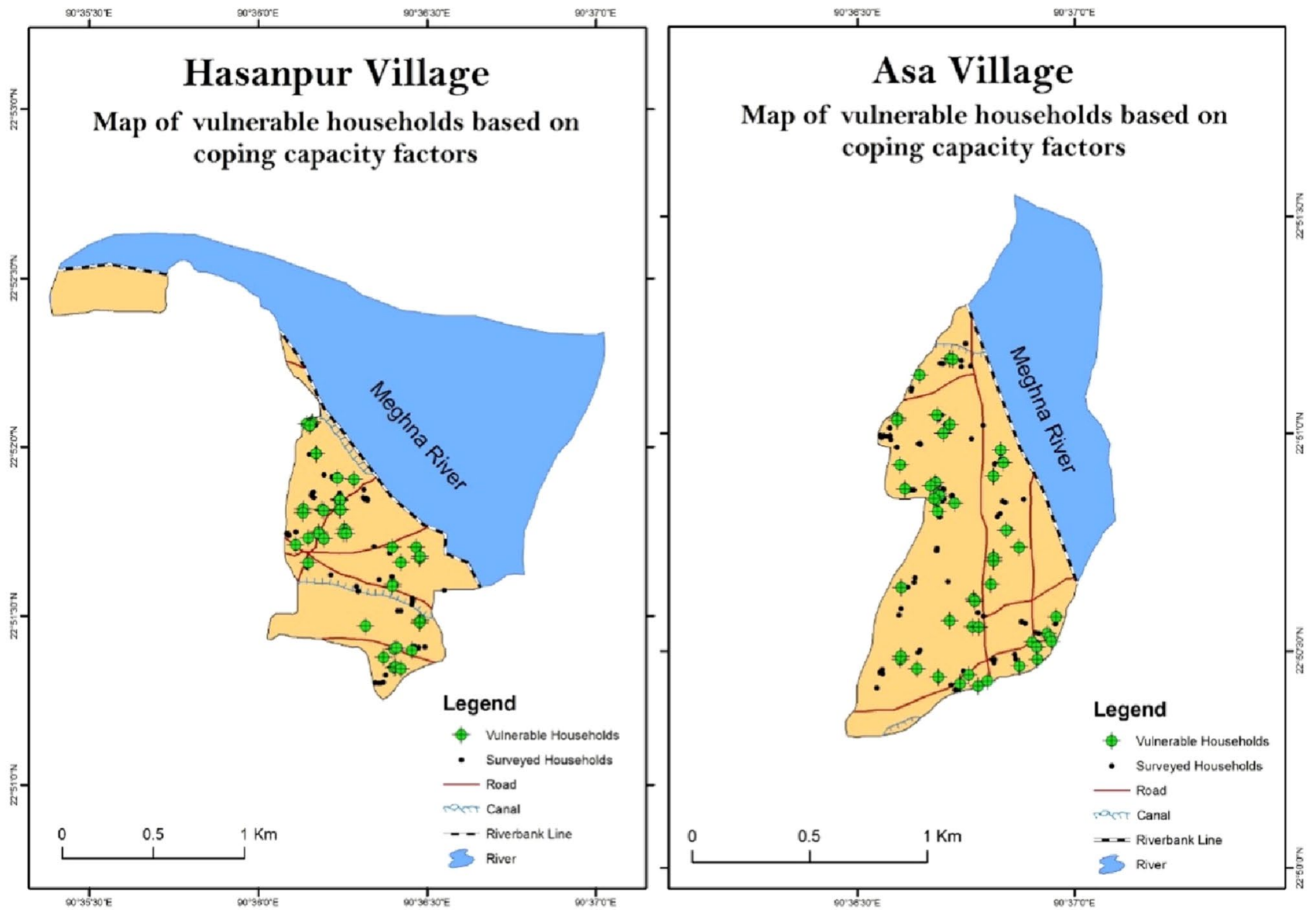

Fig. 9 Most vulnerable households based on coping capacity factors 

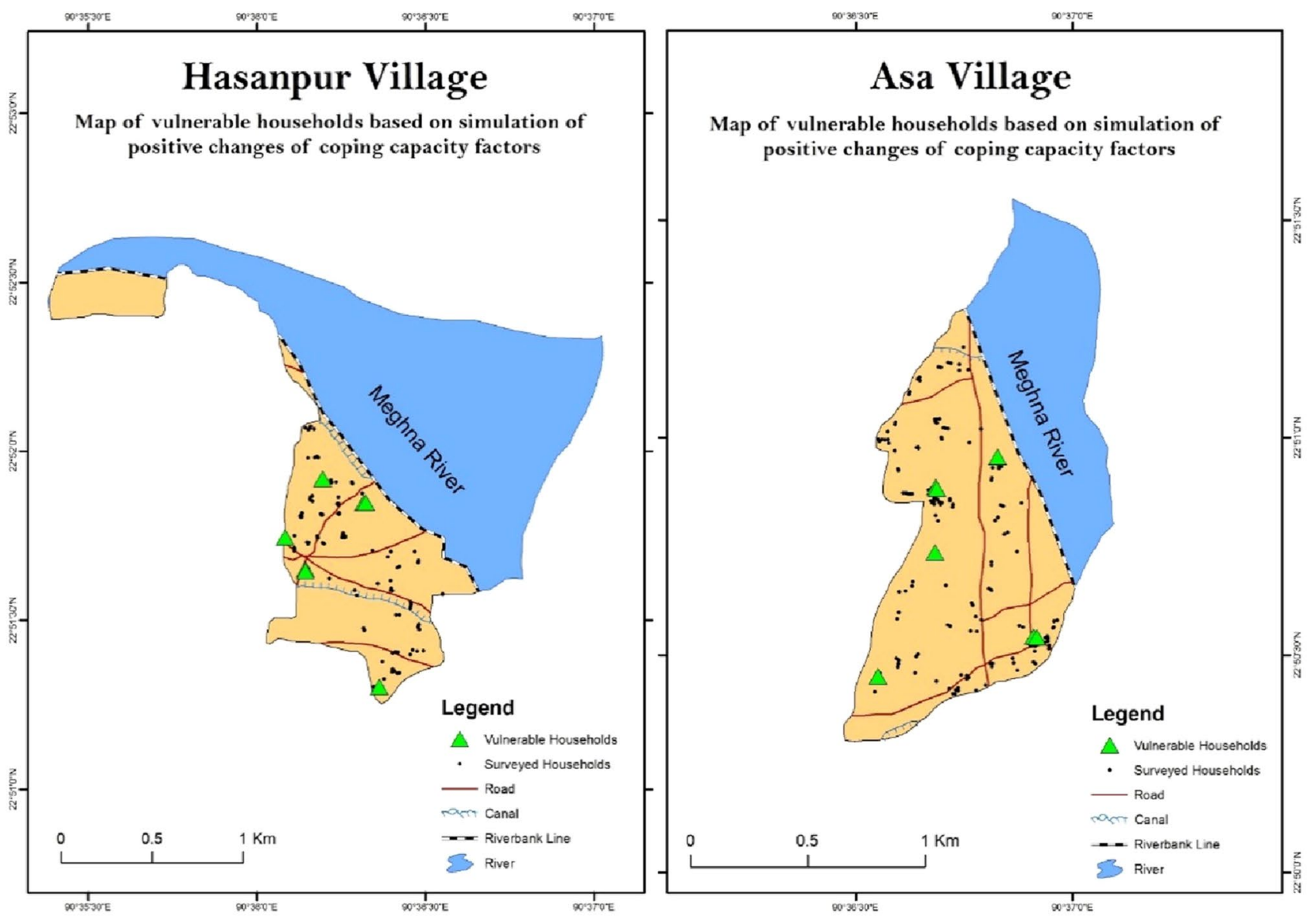

Fig. 10 Simulated vulnerable households based on the positive alterations of coping capacity factors 

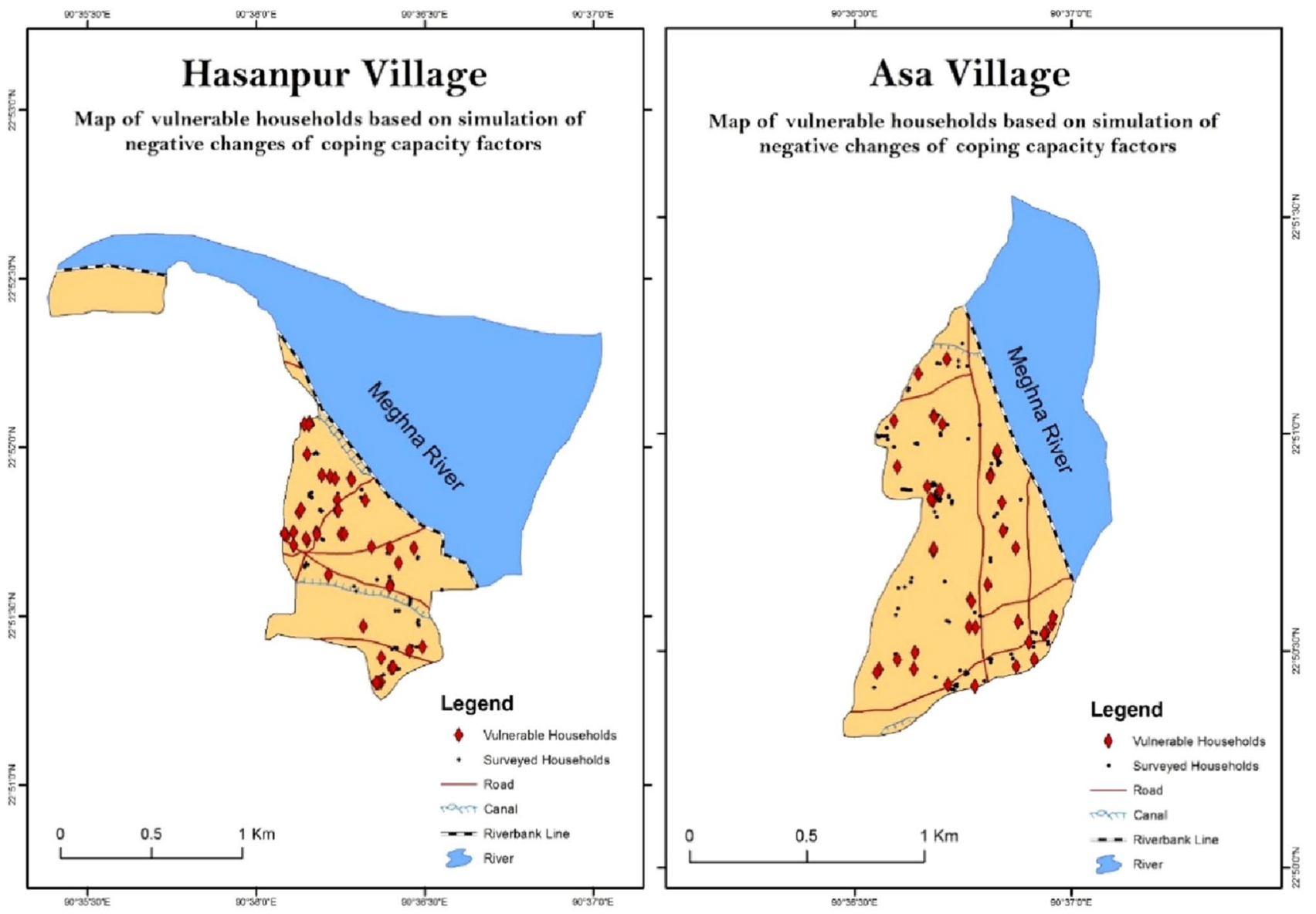

Fig. 11 Simulated vulnerable households based on the negative alterations of coping capacity factors

Author Contributions TRC initiated and contributed to the preliminary concept of the study under the supervision of ZA and SI. Afterward, TRC collected the primary data from the study area and completed the analysis. Then after collecting the secondary data, statistical, spatial data analysis, and all of the embedded maps were done by TRC under the supervision of ZA and SI. SA assists TRC while drafting the initial version. Meanwhile, SA and ZA have completed all necessary revisions and editing in the manuscript. HK provides suggestions and guidelines. Subsequently, ZA completed the final draft and revised it critically. Finally, all the authors approved this final version.

Funding This study has not received any funding for any of the research activities.

\section{Declarations}

Conflict of interest The authors declare that they have no conflict of interest.

Ethical Approval Although this study does not have any direct or indirect risks to participants, we received informed consent from the respondents. This manuscript does not contain any studies with animals performed by any of the authors.
Open Access This article is licensed under a Creative Commons Attribution 4.0 International License, which permits use, sharing, adaptation, distribution and reproduction in any medium or format, as long as you give appropriate credit to the original author(s) and the source, provide a link to the Creative Commons licence, and indicate if changes were made. The images or other third party material in this article are included in the article's Creative Commons licence, unless indicated otherwise in a credit line to the material. If material is not included in the article's Creative Commons licence and your intended use is not permitted by statutory regulation or exceeds the permitted use, you will need to obtain permission directly from the copyright holder. To view a copy of this licence, visit http://creativecommons.org/licenses/by/4.0/.

\section{References}

Adger WN (2006) Vulnerability. Glob Environ Chang 16(3):268-281 Aktar MN (2013a) Impact of climate change on riverbank erosion. Int J Sci Basic Appl Res (IJSBAR) 7(1):36-42

Aktar MN (2013b) Historical trend of riverbank erosion along the braided River Jamuna. Int J Sci Basic Appl Res (IJSBAR) 11(1):173-180

Akter S, Mallick B (2013) The poverty-vulnerability-resilience nexus: evidence from Bangladesh. Ecol Econ 96:114-124 
Alam MM (1991) Some distinctive aspects of braiding and anastomosing with reference to the Jamuna and Meghna rivers in Bangladesh. J Bangladesh Acad Sci 15:113-121

Ali SA, Khatun R, Ahmad A, Ahmad SN (2019a) Assessment of cyclone vulnerability, hazard evaluation and mitigation capacity for analyzing cyclone risk using GIS technique: a study on Sundarban Biosphere Reserve, India. Earth Syst Environ. https://doi.org/10.1007/s41748-019-00140-x

Ali SA, Khatun R, Ahmad A, Ahmad SN (2019b) Application of GIS-based analytic hierarchy process and frequency ratio model to flood vulnerable mapping and risk area estimation at Sundarban region, India. Model Earth Syst Environ. https://doi.org/ 10.1007/s40808-019-00593-z

Banglapedia, http://en.banglapedia.org/index.php?title=Mehen diganj_Upazila

BBS (Bangladesh Bureau of Statistics) (2011) Bangladesh population and housing census: Zila report, Barisal, 25-26

Blaikie P, Cannon T, Davis I, Wisner B (2014) At risk II: natural hazards, people's vulnerability and disasters. Routledge, London

Bhuiyan MAH, Kumamota T, Suzuki S (2014) Application of remote sensing and GIS for evaluation of the recent morphological characteristics of the lower Brahmaputra Jamuna River, Bangladesh. Earth Sci Inf 8(3):551-568. https://doi.org/10.1007/ s12145-014-0180-4

Bhuiyan MAH, Islam SMD, Azam G (2017) Exploring impacts and livelihood vulnerability of riverbank erosion hazard among rural household along the river Padma of Bangladesh. Environ Syst Res 6:25. https://doi.org/10.1186/s40068-017-0102-9

CEGIS (Center for Environment and Geographic Information Services) (2012) Prediction of river bank erosion along the Jamuna, the Ganges the Padma and the lower Meghna rivers, Report of BWDB

Das JD, Saraf AK (2007) Technical note: remote sensing in the mapping of the Brahmaputra/Jamuna river channel patterns and its relation to various landforms and tectonic environment. Int $\mathrm{J}$ Remote Sens 28(16):3619-3631

Das JD, Dutta T, Saraf AK (2007) Remote sensing and GIS application in change detection of the Barak river channel, N.E. India. J Indian Soc Remote Sens 35(4):301-312

Debnath J, Das N, Ahmed I, Bhowmik M (2016) Vulnerability assessment of socio economic condition due to river bank erosion: a case study on Khowai River, Tripura, India. IOSR J Humanit Soc Sci (IOSR-JHSS) 21(5):37-42

Emrich CT, Cutter SL (2011) Social vulnerability to climate-sensitive hazards in the southern United States. Weather Clim Soc 3(3): 193-208

Fujita Y, Kawaguchi M, Hai TP (2000) A conceptual model for erosion processes of high river bank. Annu J Hydraul Eng 44:753-758

Haque CE, Hossain Z (1988) Riverbank erosion in Bangladesh. Geogr Rev 78(1):20-31. https://doi.org/10.2307/214303

Haskoning (1992) Meghna River Bank Protection Short Term Study, Haskoning, Royal Dutch Consulting Engineers and Architects in Association with Delft Hydraulics and Bangladesh Engineering \& Technological Services for Bangladesh Water Development Board: Dhaka, Bangladesh

Hossain MN (2015) Analysis of human vulnerability to cyclones and storm surges based on influencing physical and socioeconomic factors: evidences from coastal Bangladesh. Int J Disaster Risk Reduct 13:66-75

Hossain MN, Paul SK (2017) Simulation of physical and socioeconomic factors of vulnerability to cyclones and storm surges using GIS: a case study. GeoJournal. https://doi.org/10.1007/ s10708-015-9668-9

Hossain MN, Paul SK (2018) Vulnerability factors and effectiveness of disaster mitigation measures in the Bangladesh coast. Earth Syst Environ 2:55-65. https://doi.org/10.1007/ s41748-018-0034-1
Jain SK, Singh RD, Jain MK, Lohani AK (2005) Delineation of floodprone areas using remote sensing techniques. Water Resour Manag 19:333. https://doi.org/10.1007/s11269-005-3281-5

Klaassen GJ, Douben K, van der Wal M (2002) Novel approaches in river engineering, In: Bousmar D, Zech Y (eds) River flow 2002: proceedings of the international conference on fluvial hydraulics, Louvain-la-Neuve, pp 27-43

Madej MA, Weaver WE, Hagans DK (1994) Analysis of bank erosion on the Merced River, Yosemite Valley, Yosemite National Park, California, USA. Environ Manag 18(2):235-250

Nath B, Naznin SN, Alak P (2013) Trends analysis of river bank erosion at Chandpur, Bangladesh: a remote sensing and GIS approach. Int J Geomatics Geosci 3(3):454-463

Paul SK (2013) Vulnerability concepts and its application in various fields: a review on the geographical perspective. J Life Earth Sci 8:63-81

Pati JK, Lal J, Prakash K, Bhusan R (2008) Spatio-temporal shift of western bank of the Ganga River at Allahabad city and its implications. J Indian Soc Remote Sens 36(3):289-297. https://doi.org/10.1007/ s12524-008-0030-2

Phillip G, Gupta RP, Bhatatcharya AB (1989) Channel migration studies in the middle Ganga basin, India using remote sensing. Int J Remote Sens 10(6): 1141-1149

Rahman MR (2010) Impact of riverbank erosion hazard in the Jamuna floodplain areas in Bangladesh. J Sci Found 8(1 \& 2):55-65

Roche S, Propeck-Zimmermann E, Mericskay B (2013) Geo Web and crisis management: issues and perspectives of volunteered geographic information. GeoJournal 78(1):21-40

Roy DK, Goswami S, Ahmed T, Saha MK, Emon MH, Rahim MA (2017) Socio-economic impacts of river bank erosion on Durgapasha Union in Bakerganj Upazila, Bangladesh. Barisal Univ J 1(4):165-183

Sahana M, Sajjad H (2019) Vulnerability to storm surge flood using remote sensing and GIS techniques: a study on Sundarban Biosphere Reserve, India. Remote Sens Appl Soc Environ 13:106-120

Salam MA, Ross LG, Beveridge CM (2003) A comparison of development opportunities for crab and shrimp aquaculture in southwestern Bangladesh, using GIS modelling. Aquaculture 220(1):477-494

Saleem A, Dewan A, Rahman MM, Nawfee SM, Karim R, Lu XX (2020) Spatial and temporal variations of erosion and accretion: a case of a large tropical river. Earth Syst Environ 4:167-181. https://doi.org/ 10.1007/s41748-019-00143-8

Smit B, Wandel J (2006) Adaptation, adaptive capacity and vulnerability. Glob Environ Chang 16(2):282-292

Sokolowski JA, Banks CM (eds) (2011) Principles of modeling and simulation: a multidisciplinary approach. Wiley, New York

Srivastava A (2015) Role of GI services in emergency response management in India. Recovery from the Indian Ocean Tsunami. Springer, Tokyo, pp 299-314

Tangri AK (2000) Application of remote sensing techniques in monitoring the spatial and temporal evolution of fluvio-geomorphic features in Ganga basin with specific reference to their impact on engineering structures. In: Sinha R (ed) Proceedings of the workshop on Fluvial geomorphology with special reference to floodplains. Indian Institute of Technology, Kanpur

Taramelli A, Valentini E, Sterlacchini S (2015) A GIS based approach for hurricane hazard and vulnerability assessment in the Cayman Islands. Ocean Coast Manag 108:116-130

Thakur PK, Laha C, Aggarwal SP (2011) River bank erosion hazard study of river Ganga, upstream of Farakka barrage using remote sensing and GIS. Nat Hazards. https://doi.org/10.1007/s11069-011-9944-z

Wang Y, Colby JD, Mulcahy KA (2002) An efficient method for mapping flood extent in a coastal flood plain using Landsat TM and DEM data. Int J Remote Sens 23(18):3681-3696

Yamane (1967) Statistics: an introductory analysis. Harper and Row, New York, NY 